\title{
Aortocoronary Bypass Surgery in a Patient with Severely Calcified Aorta and Coronary Arteries: Does Radiotherapy Induce it?
}

\author{
Ciddi Aort ve Koroner Kalsifikasyon Olan Hastada Aortokoroner Bypass: Radyoterapi Hastalı̆ıı Uyarır mı?
}

Hakan Bingöl

Department of Cardiovascular Surgery, Karabük Medical Hospital, Karabük, Turkey

\begin{abstract}
Mediastinal irradiation has been shown to induce accelerated arteriosclerosis of calcification of thoracic aorta. Some people, with a history of cured malignant diseases, undergo Coronary Artery Bypass Graft (CABG) surgery and the adverse effects of previous radiotherapy on the outcome after CABG is known, but there are few reports on radiotherapy induced coronary and aortic calcification, which might affect the surgical outcome. We hereby report a patient who underwent CABG with severe calcification of the coronary arteries and thoracic aorta. In our opinion, radiotherapy, which was done 28 years earlier, was the most likely responsible factor. (JAREM 2013; 3: 38-40)
\end{abstract}

Key Words: Radiotherapy, coronary calcification, coronary artery bypass

\section{ÖZET}

Mediastene uygulanan ışın tedavisinin koroner arterlerde aterosklerozu ve aortoda kalsifikasyonu arttırdığı gösterilmiştir. Daha once malign hastalıklara bağlı ışın tedavisi uygulanan bazı hastalarda önceki ışın tedavisine bağlı yan etkiler görülebilir. Fakat daha önceki ışın tedavisinin koroner bypass operasyonu sonrası hastanın prognozunu etkileyecek kadar coroner ve aort kalsifikasyonuna yol açıp açmadığı hakkında çok az bilgi vardır. Biz koroner bypass operasyonuna aldığımız ve aorta ile koroner arterlerinde ciddi kalsifikasyon bulunan bir hastayı sunuyoruz. Bize gore ciddi kalsifikasyonlarının en büyük nedeni 28 yıl once göğüs tümörü tanısı ile ışın tedavisi uygulanmış olmasıydı. (JAREM 2013; 3: 38-40)

Anahtar Sözcükler: Radyoterapi, koroner kalsifikasyon, aorto-koroner bypass

\section{INTRODUCTION}

Coronary artery calcification is a common entity affecting both sexes and is associated with other cardiovascular risk factors such as age, gender, LDL or total cholesterol level, body mass index and percent body fat or previous irradiation (1-3). Calcifications of the ascending or descending thoracic aorta might accompany coronary artery calcification and they are easily visible on Chest $\mathrm{X}$-Ray (CXR). Mediastinal irradiation has also been shown to induce diseases such as pericarditis, valvular dysfunction, conduction abnormalities, accelerated arteriosclerosis of coronary arteries, as well as calcification of the thoracic aorta (3).

We hereby report a patient with severe calcification of the coronary arteries and thoracic aorta, who underwent Coronary Artery Bypass Graft (CABG) surgery for Ischemic Heart Disease. After we evaluated the possible causes of such severe calcification, we regarded the previous radiotherapy to be the most likely cause.

\section{CASE REPORT}

The 78 year old female patient presented to emergency department with a sudden onset of dyspnea and chest pain. She also had a history of left breast tumor, 28 years previously which was treated successfully by a combination of radical mastectomy and radiotherapy. Although the information regarding the dose and extent of radiation was not available, she did not describe any recurrence of tumor after the initial treatment.

Despite ECG and initial laboratory studies such as cardiac enzymes, the patient was hospitalized due to her advanced age and serious clinical condition. Dyspnea resolved after supportive therapy and coronary angiogram was performed the next day, which revealed critical stenosis in two vessels. The patient was advised to have a Coronary Artery Bypass Operation (CABG).

After being transferred to the cardiac surgery department, preoperative routine CXR was obtained, which showed severe calcification in the ascending and descending thoracic aorta. (Figure 1). The calcification at RCA was also visible on fluoroscopy, which showed totally occlusion (Figure 2, 3).

The patient was taken to theatre, and the CABG operation was performed with a median sternotomy incision, using standard aortic and right atrial cannulation, non-pulsatile cardiopulmonary bypass (CPB) and moderate hypothermia. Although the ascending aorta was mostly calcified as seen at CXR, cannulation was performed through a soft spot found at the distal part of the ascending aorta, and cross clamp application was performed in the usual fashion. Myocardial protection was achieved by cold crystalloid cardioplegia and topical cooling. On exploration following intraoperative arteriotomy, severe calcification was noted at the Left anterior descend- 


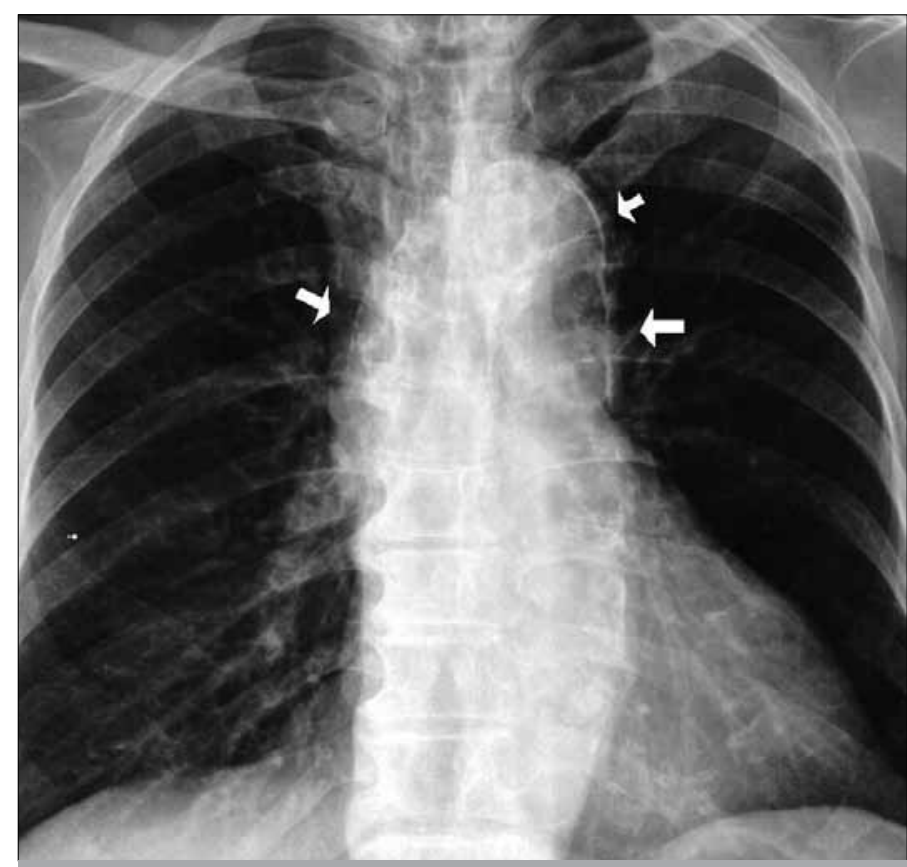

Figure 1. Severe calcification of ascending and descending thoracic aorta, visible at CXR

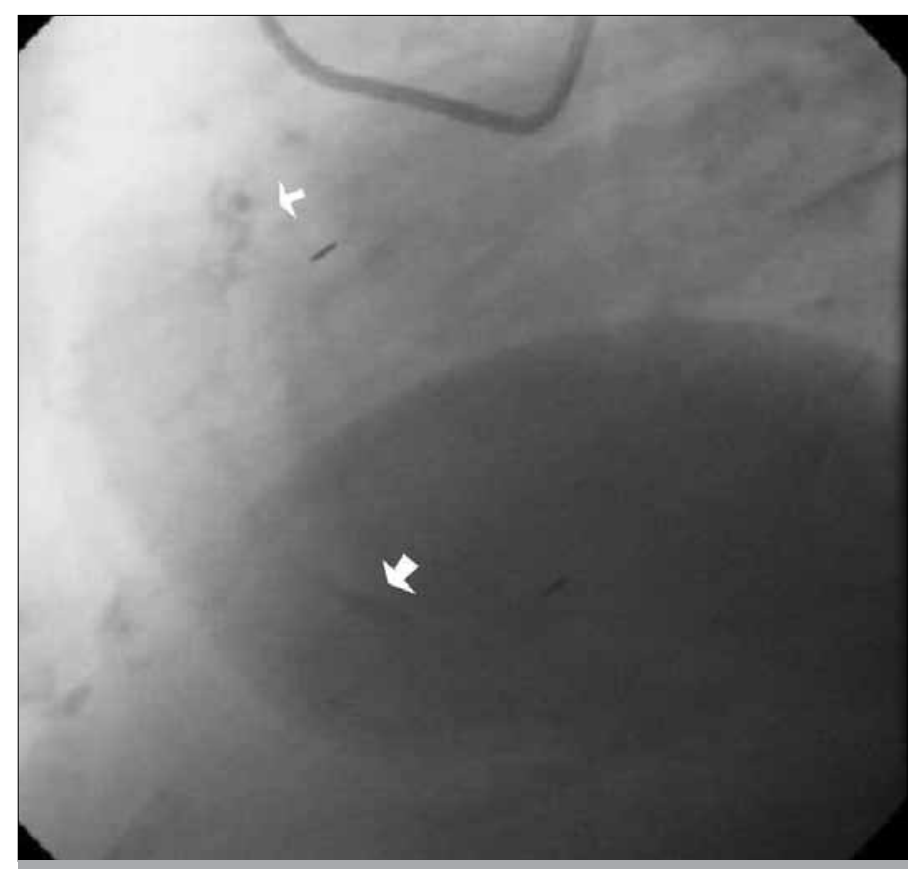

Figure 2. Calcified RCA at fluoroscopy

ing and Right coronary arteries. So, anastomoses were performed with great care to avoid any mobilization of calcified plaques.

The patient was extubated on the $8^{\text {th }}$ post operative hour. Her recovery was uneventful, except for some respiratory dysfunction due to a small atelectatic area in the right lower lobe. Fortunately, there was no sign of neurologic injury, or perioperative myocardial infarction, which might have been the result of any dislodgement in the calcified plaques. The atelectasis resolved after frequent mobilizations and respiratory exercises, and the patient was discharged at post operative $11^{\text {th }}$ day.

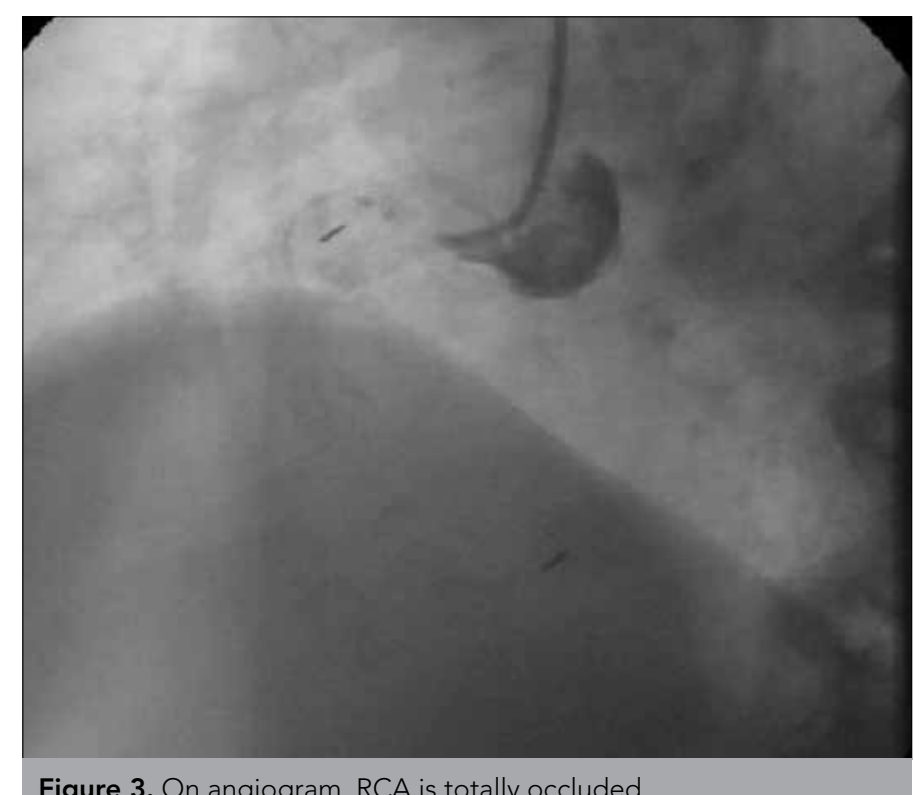

Figure 3. On angiogram, RCA is totally occluded

\section{DISCUSSION}

Calcification of the arteries is a common entitiy, and its prevalence increases with age (4). Clinically important calcification occurs mostly in the ascending aorta, coronary or carotid arteries. Even though dense arterial calcification might be seen at plain radiograms of the associated body part, calcification of all the vessel beds might be more accurately detected by Multi Slice Computed Tomography (MSCT). Arterial calcification is more common in males (4). Generally, calcification increases with the increasing number of cardiovascular risk factors, also calcification of coronary and carotid arteries are more prevalent among males, whereas calcification of the aortic arch is more prevalent among females. In a population based study with 600 participants, all of the participants over 80 years old were found to have vessel calcification detected by MSCT (4).

There are various causes of vessel calcification and the most common cause is atherosclerosis. It is also the major cause of cardiovascular disease and atherosclerotic lesions have different histological and histochemical compositions at different stages of their natural history. The more advanced atherosclerotic lesions might contain calcium deposits within the arterial wall, so calcification might be considered as the natural part of the atherosclerotic process.

Another reason for calcification is dystrophia. Dystrophic calcification might be seen in any part of body, where tissue necroses occur (5). These might be in soft tissues, around heart valves, and within the arterial wall (5). Radiotherapy is a treatment modality, which uses high dose irradiation to attenuate or kill malignant cells; this irradiation causes some tissue necrosis, might also damage the arterial wall and cause calcification. Radiotherapy has also been reported to induce premature atherosclerosis of coronary arteries, pericarditis, valvular dysfunction, conduction abnormalities and calcification of the ascending aorta (1).

Vessel calcification is still problematic, especially for cardiac surgeons because of cannulation and perioperative complications. 
It might change the operative strategy, and increase the rate of post-operative complications. Severe coronary calcification might herald a heavy atherosclerotic plaque burden in a patient with ischemic heart disease. On the other hand, severe aortic calcification might change the cross clamp technique during cardiac surgery [6], and may cause post-operative neurologic dysfunction due to atheroembolus, or increase the risk of perioperative myocardial infarction. The stiff ascending aorta, which does not permit the application of a cross clamp, is called porcelain aorta [6]. In our case, even though the dense calcification at the thoracic aorta was visible on CXR, it was not considered a porcelain aorta, because the cross clamp application was feasible.

\section{CONCLUSION}

After considering the atherosclerotic risk factors of the patient, and such a dense calcification affecting both thoracic aorta and coronary arteries, we thought that we should seek another cause other than atherosclerotic calcification. Although we do not know the dose and extent of the radiotherapy she received 28 years previously, we concluded that it is worth considering as a causative agent. Eventually, checking the relevant literature on the subject dispelled our myths, answered our questions, and we named radiotherapy as the causative agent.

\section{Conflict of Interest / Çıkar Çatışması}

No conflict of interest was declared by the authors. Yazarlar herhangi bir çıkar çatışması bildirmemişlerdir.
Peer-review: Externally peer-reviewed.

Hakem değerlendirmesi: Dış bağımsız.

\section{Author Contributions / Yazar Katkıları}

Concept / Fikir - H.B.; Design / Tasarım - H.B; Supervision / Denetleme - H.B.; Funding / Kaynaklar - H.B.; Materials / Malzemeler - H.B.; Data Collection and/or Processing / Veri toplanması ve/veya işlemesi- H.B.; Analysis and/or Interpretation / Analiz ve/veya yorum - H.B.; Literature Review / Literatür taraması - H.B.; Writer / Yazıyı yazan - H.B.; Critical Review / Eleştirel Inceleme - H.B.; Other / Diğer - H.B.

\section{REFERENCES}

1. Daitoku K, Fukui K, Ichinoseki I, Munakata M, Takahashi S, Fukuda I. Radiotherapy-induced aortic valve disease associated with porcelain aorta. Jpn J Thorac Cardiovasc Surg 2004; 52: 349-52. [CrossRef]

2. Erez E, Eldar S, Sharoni E, Abramov D, Sulkes A, Vidne BA. Coronary artery operation in patients after breast cancer therapy. Ann Thorac Surg 1998; 66: 1312-7. [CrossRef]

3. Allison MA, Wrigth $\mathrm{CM}$. Age and gender are strongest clinical correlates of prevalent coronary calcification (R1). Int J of Cardiol 2005; 98: 325-30. [CrossRef]

4. Odink $A E$, van der Lugt A, Hofman A, Hunink MG, Breteler MM, Krestin GP, et al. Association between calcification in the coronary arteries, aortic arch and carotid arteries: the Rotterdam study. Atherosclerosis 2007; 193: 408-13. [CrossRef]

5. Kumar V, Cotran R S, Robbins S. Basic pathology, 6th edition. Philadelphia 2000; WB Saunders Company.

6. Ooi A, lyenger S, Langley SM, Haw MP. Endovascular clamping of porcelain aorta in aortic valve surgery using Foley Catheter. Heart Lung and Circ 2006; 15: 194-6. [CrossRef] 